\title{
Botanical Study and in vitro Antibacterial Activity of Bersama abyssinica Fresen. (Melianthaceae) on Multi-Resistant Staphylococcus aureus Strains
}

\author{
Kouadio BENE ${ }^{1}$, Nathalie K. GUESSENND ${ }^{2}$, Djeneb CAMARA ${ }^{3}$, Guédé N. ZIRIHI ${ }^{4}$, et Mireille DOSSO \\ ${ }^{1,3,4}$ Laboratoire de Botanique, UFR Biosciences, Université Félix HOUPHOUËT-BOIGNY, Cocody, Abidjan ; 22 BP 582 Abidjan 22. \\ ${ }^{2,5}$ Laboratoire de Bactériologie-Virologie, Institut Pasteur de Côte d'Ivoire, 08 BP 1563 Abidjan 08
}

\begin{abstract}
Objective: The objective of this study was to find new natural substances (bioactive)having antibacterial activity on multiresistant strains of Staphylococcus aureus. Methods and Results: The methods of dissemination swab on Muller-Hinton agar and double dilution were used to evaluate the antibacterial activity of aqueous total extract of the stembark of Bersama abyssinica. All multi-resistant strains of Staphylococcus aureus and the reference strain (ATCC 25923) were sensitive to aqueous total extract (ATE)of the stem bark of B. abyssinica. Conclusion and Application:ATE had a bactericidal effect on different strains tested. MBC ranged from $1.563 \pm 0.0$ to $0.098 \pm 0.0 \mathrm{mg} / \mathrm{ml}$. This result justifies the traditional use of the stem bark of Bersamain treating skin diseases. We have hope on the development of this new substances that can fight the multi-resitantes strains of Staphylococcus aureus at least with the crude extract of the plant.
\end{abstract}

Keywords: Bersama abyssinica, multi-resistant strains, Staphylococcus aureus, aqueous total extract

\section{Introduction}

Antibiotics widely used for the treatment of infectious diseases are under constant threat due to the emergence of antibiotic resistant pathogens such as meticiline resistantStaphylococcus aureus(MRSA) [1] [2]. This antibiotic resistance in pathogenic microorganisms has caused a lot of premature deaths and has become a public health problem worldwide [3]. Many cases of multidrug resistance have been reported inCôte-d'Ivoire and in other sub-Saharan countries[4]. Staphylococcus aureus is responsible for endocarditis, and wound infections. It's responsible for bacterial infections and one of the three major causes of nosocomial infections [5]. These strains also cause skin infections: boils, folliculitis, paronychia, breast abscess in women and nursing animals. Mucosal infections are common and can affect the eyes (conjunctivitis), ears (otitis), the genital area (endometritis, pelvic inflammatory disease) or respiratory organ (pneumonia, pleurisy). Among these Staphylococci, the strains marked R (Resistant) are those of which there is a high probability of treatment failure, regardless of the type and dose of antibiotic treatment used[6].

In view of the increasingly growing of multiple resistant disease causing bacteria, and the wide spectrum of infections caused by Staphylococcus aureus, the search for new antimicrobial substances from medicinal plants, capable of destroying multi-resistant strains becomes necessary. Indeed, antimicrobial compounds from plants extracts are capable of inhibiting bacterial growth by acting on cellular targets different from those covered by the currently used antibiotics such as penicillins, macrolidesortetracyclines. They could also have a significant clinical value in the treatment of infections caused by microbial resistant strains[7]. Thus, an ethnobotanical study was conducted in the Region of Transua, District of Zanzan (Côte d'Ivoire), we foundBersama abyssinica Fresen. (Melianthaceae), a plant widely used in the treatment of skin diseases.

Previous work has shown that Bersama abyssinica is used in the treatment of various diseases: cancer, spasms, infections, male infertility, diabetes [8], diarrhea, cholera, intestinal worms, amebiasis dysentery, syphilis, gonorrhea [9], malaria and general fatigue [10] [11].

The botanical study conducted aimed at evaluating the antibacterial activity of aqueous total extract of the stem bark of Bersama abyssinica on the in vitro growth of some multi-resistant strains of Staphylococcus aureus.

\section{Material}

\subsection{Plant Material}

Going by our ethnobotanical investigation in the Region of Transua (District of Zanzan,Côte d'Ivoire), it appears that Bersama abyssinica plant is widely used in the treatment of microbial diseases. The stem bark was harvested, cut, washed with water and dried under the shade. These dried plant parts,using a grinder were then reduced to a fine powder.

\section{Botanical Study of Bersama abyssinica}

Synonym: Bersama engleriana Gürke (1892).

\section{Phytogeography}

Bersama abyssinica belongs to the family Melianthaceae; the genus Bersama made up of eight species, all found in Africa. There is a wide variability in Bersama, this distinction has enabled the identification of many species, subspecies and varieties. The Ivorian species is the paullinioides variety. 


\section{International Journal of Science and Research (IJSR) \\ ISSN (Online): 2319-7064}

Index Copernicus Value (2013): 6.14 | Impact Factor (2014): 5.611

Bersama abyssinica is a very common plant in Africa. It is found in West Africa (except in Republic of Benin), the Horn of Africa and southern part of the continent (Angola, Zambia, Zimbabwe and Mozambique).

Our sample of B. abyssinica was compared to that of the National Centre of Floristic : Region of Bondoukou, April 7, 1966, No. 8704 Ake-Assi.

Bersama abyssinica is a shrub up to $6 \mathrm{~m}$ in height, often with twisted trunk. The leaves,imparipinnately compound, measuring up to $60 \mathrm{~cm}$ long, contain from six to nine pairs (or more) of glabrescent leaflets; the spine is winged. The inflorescences, solitary racemes or few, are axillary near the ends of branches. Flowers, white or yellowish, about $2 \mathrm{~cm}$ in length. Fruits, reddish, up to $2 \mathrm{~cm}$ in length, are dehiscent at maturity. The seeds are surrounded by an orange-red aril[12].

\subsection{Bacterial Material}

Made up of a reference strain (ATCC 25923) and five multiresistant strains of Staphylococcus aureus obtained from biological products (Table 1). They are Gram-positive bacteria $($ Gram +$)$, spherical, with a diameter of $1 \mu \mathrm{m}$, in diplococcior small cluster (cluster of grapes) motionless,spore, not encapsulated. This bacterium is an aero-anaerobic germ respiratory and fermentative metabolism, catalase positive [13]. They are provided by the Antibiotics Unit, Natural Substances and Monitoring of Microorganisms for Anti-Infective (ASSURMI) and the Department of Bacteriology and Virology of the Pasteur Institute of Cote d'Ivoire (IPCI).

Table 1: List of strains studied

\begin{tabular}{|c|c|c|c|}
\hline Strain & Codes & Profile & $\begin{array}{c}\text { Biological } \\
\text { products }\end{array}$ \\
\hline \multirow{4}{*}{$\begin{array}{c}\text { Staphylococcus } \\
\text { aureus }\end{array}$} & ATCC 25923 & Sensitive to methicillin & - \\
\cline { 2 - 4 } & $039 \mathrm{C} / 11$ & Methicillin resistant & Pus \\
\cline { 2 - 4 } & $237 \mathrm{YO} / 14$ & Methicillin resistant & Pus \\
\cline { 2 - 4 } & $446 \mathrm{UB} / 15$ & Methicillin resistant & Pus \\
\cline { 2 - 4 } & $524 \mathrm{YO} / 14$ & Methicillin resistant & Blood \\
\cline { 2 - 4 } & $833 \mathrm{UB} / 14$ & Methicillin resistant & Blood \\
\hline
\end{tabular}

\section{Methods}

In this part, the tests are done in triplicate.

\subsection{Preparation of the aqueous total extract (ATE)}

One hundred grams (100 g) of stem bark powder were homogenized in 1 liter of distilled water in a blender (mixer) for three times three minutes at room temperature. The homogenate was first squeezed in a square of clean white cloth (the mac was placed again in the blender to repeat the operation, it's an extraction by exhaustion) and then filtered through cotton wool, and finally on Whatman paper. Using an oven set at $50^{\circ} \mathrm{C}$, the extraction solvent was removed. The evaporate was recovered in the form of dry powder and constituted the aqueous total extract (ATE) [14] [15].

\subsection{Yield Calculation}

The yield is the amount of extract obtained from the plant powder. It is expressed as a percentage or without any unit. In practice, it is determined by the ratio of weight of the solids content after evaporation by the weight of the dry powder of the plant material used for the extraction, multiplied by 100 . This gives the following formula: $\mathrm{Yd}=$ ( $\mathrm{m} \mathrm{x} 100) /$ M. (Yd: Extraction yield in percentage, m: mass in grams of the dry extract, M: mass in grams of the drug powder).

\subsection{Sterility test of ATE}

This test verified that the extract contained no germ. For this, $0.1 \mathrm{~g}$ of the extract was enriched by adding in $10 \mathrm{ml}$ of thioglycholate broth and incubated at $37^{\circ} \mathrm{C}$ for $24 \mathrm{~h}$. After that, the broth was plated on a Petri dish containing ordinary agar and incubated under the same conditions. The extract is declared sterile, if no colony is visible on the agar box.

\subsection{Effectiveness test}

The strain sensitivity to aqueous total extract of Bersama was performed using the agar diffusion method. Mueller Hinton agar were inoculated with a swab. A total of 4 wells of $6 \mathrm{~mm}$ in diameter were then made in the agar, of which 1 served as control well in the center of the agar and containing only sterile distilled water (TS). Each of the three wells received $50 \mu \mathrm{l}$ of the test substance into the concentrations of 100,50 and $25 \mathrm{mg} / \mathrm{ml}\left(\mathrm{C}_{1}, \mathrm{C}_{2}\right.$ and $\mathrm{C}_{3}$ respectively). After $30 \mathrm{~min}$ diffusion at laboratory temperature, the plates were incubated at $37^{\circ} \mathrm{C}$ for $24 \mathrm{~h}$. The presence or absenceof inhibition zone was observed and measured with a caliper or ruler in millimeters $(\mathrm{mm})$. The results are expressed as the diameter of inhibition zone. Therefore, according to the sensitivity of strain, we have strains that are[16]:

- Not susceptible or resistant: diameter less than $8 \mathrm{~mm}$;

- Susceptible: diameter between 9 and $14 \mathrm{~mm}$;

- Very sensitive: diameter between 15 and $19 \mathrm{~mm}$,

- Extremely sensitive: diameter greater than $20 \mathrm{~mm}$.

\subsection{Preparation of the concentration range of plant extracts}

The range of concentration of plant extract was prepared in twelve test tubesnumbered $T_{1}$ to $T_{13}$ by the method of double dilution in geometrical ratio $1 / 2$. The concentrations ranged from $\mathrm{C}_{1}=100$ to $\mathrm{C}_{13}=0.0244 \mathrm{mg} / \mathrm{ml}$.

\subsection{Preparation of the inoculum}

The bacterial inoculum was prepared from colonies of less than 18-24 $\mathrm{h}$ in Mueller Hinton broth (BMH). A single colony of the bacterial culture was removed using a platinum loop and homogenized in $10 \mathrm{ml}$ broth and incubated for $3 \mathrm{~h}$ at $37^{\circ} \mathrm{C}$ for a pre-culture. After incubation, a volume of $0.3 \mathrm{ml}$ was taken and was added to $10 \mathrm{ml}$ of sterile BMH. This made up bacterial suspension valued at approximately $10^{6}$ cells $/ \mathrm{ml}$ and constituted $10^{\circ}$ dilusion or the pure inoculum. 


\section{International Journal of Science and Research (IJSR) \\ ISSN (Online): 2319-7064 \\ Index Copernicus Value (2013): 6.14 | Impact Factor (2014): 5.611}

\subsection{Counting of bacterial inoculum}

The counting of the inoculum was performed by dilution from 10 to 10 from the pure inoculum $\left(10^{0}\right)$ until the $10^{-4}$ dilution. We obtained 4 dilutions $10^{-1}, 10^{-2}, 10^{-3}$ and $10^{-4}$. These various dilutions and the pure inoculum were inoculated with a calibrated loop of $2 \mu \mathrm{l}$ per striae of $5 \mathrm{~cm}$ long on Mueller Hinton agar and incubated at $37^{\circ} \mathrm{C}$ for $24 \mathrm{~h}$. This preparation constituted box A.

\subsection{Determination of the minimum inhibitory concentration (MIC)}

The MIC determination was made using two 96 well microplates for each series. In a series of wells numbered from $\mathrm{C}_{1}$ to $\mathrm{C}_{7}$ (first microplate) and $\mathrm{C}_{8}$ to $\mathrm{C}_{13}$ (second microplate) and each of the six strains $\left(\mathrm{S}_{1}-\mathrm{S}_{6}\right)$ were added $0.2 \mathrm{ml}$ of pure inoculum of each bacterial strain of Staphylococcus aureus. The TS ( Sterility Control), contains $0.4 \mathrm{ml}$ of sterile BMH. Then it was added to the wells $\left(\mathrm{S}_{1}\right.$ to $\left.\mathrm{S}_{6}\right), 0.2 \mathrm{ml}$ of plant extract according to the prepared concentration range. This distribution of plant extract was made such that $0.2 \mathrm{ml}$ of plant extract (ATE) of $200 \mathrm{mg} / \mathrm{ml}$ was transferred into the wells $\mathrm{C}_{1} ; \mathrm{C}_{2}$ wells received $0.2 \mathrm{ml}$ of $100 \mathrm{mg} / \mathrm{ml}$ and so on until $\mathrm{C}_{13}$ well where $0.2 \mathrm{ml}$ of the solution of $0.0244 \mathrm{mg} / \mathrm{ml}$ was added. TC well (Control well) received $0.2 \mathrm{ml}$ of sterile $\mathrm{BMH}$ and $0.2 \mathrm{ml}$ of sterile distilled water. Due to the volume / volume dilutionthus formed, the concentration in the wells were halved. Thus, the final concentrations in the wells were evolving $C_{1}=100 \mathrm{mg} / \mathrm{ml}$ to $\mathrm{C}_{7}=1.563 \mathrm{mg} / \mathrm{ml}$ in the first microplate and $\mathrm{C}_{8}=0.781$ to $\mathrm{C}_{13}=0.0244 \mathrm{mg} / \mathrm{ml}$ in the second microplate. These plates were incubated at $37^{\circ} \mathrm{C}$ for $24 \mathrm{~h}$.

The MIC (Minimum Inhibitory Concentration) is the lowest concentration of extract for which no bacterial growth was observed after 24 hours of incubation time. It's determination was made by observing the turbidity induced by the growth of studied germs in each tube. The MIC was the lowest concentration value for which there was no germs growth visible to the naked eyes.

\subsection{Determination of minimal bactericidal concentration (MBC)}

The minimal bactericidal concentration (MBC) is the lowest concentration of antibactrial agent that leaves at most $0.01 \%$ of surviving germs. Using a calibrated loop $2 \mu \mathrm{l}$, the tube contents in which no germs was observed were collected and seeded on Mueller-Hinton agar starting with the MIC tube. Seeding was done by parallel stripes of $5 \mathrm{~cm}$ long on the surface of the agar. This constitute the box B.

After $24 \mathrm{~h}$ of incubation in an incubator at $37^{\circ} \mathrm{C}$ the number of colonies on the streaks was compared to those of the box of the inoculum. Thus, the first experimental tube, of which germs count on the streak is less than or equal to $10^{-4}$ dilution represent the $\mathrm{MBC}$

\subsection{Modalityof ATE action}

The MBC / MICration is used to specify the modality of a substance [17].

If the result:

- $\mathrm{MBC} / \mathrm{MIC} \leq 2$, the substance is said to be bactericidal

- $\mathrm{MBC} / \mathrm{MIC}>2$, the substance is said to be bacteriostatic.

\section{Results}

\subsection{Yield for aqueous total extract (ATE)}

For hundred grams (100g) of Bersama abyssinicapowder, $25.3 \pm 1.0$ grams of ATE was obtained,that is a yield = $25.3 \pm 1.0 \%$

\subsection{Sterility test}

Sterility tests showed that ATE of stem bark of B. abyssinica shows no signs of contamination.

\subsection{Effectiveness test}

The diameters of the inhibition zones are reported in Table 2. It is noted that ATE had a good inhibitory activity, with different concentrations tested on bacterial strains. Having diameter of inhibition ranging from $11.1 \pm 0.1$ to $18,0 \pm 0.3$ $\mathrm{mg} / \mathrm{ml}$.

Table 2: Diameters of the zones of inhibition in millimeters $(\mathrm{mm})$

\begin{tabular}{|c|c|c|c|c|c|}
\hline \multicolumn{2}{|c|}{} & \multicolumn{3}{|c|}{ Concentrations $(\mathrm{mg} / \mathrm{ml})$} & \multirow{2}{*}{$T C$} \\
\hline Strain & Codes & $C_{l}=100$ & $C_{2}=50$ & $C_{3}=25$ & \\
\hline \multirow{4}{*}{ Staphylococcus aureus } & $\mathrm{ATCC} 25923$ & $15,1 \pm 0,1$ & $13,1 \pm 0,1$ & $11,2 \pm 0,2$ & $6 \pm 0,0$ \\
\cline { 2 - 6 } & $039 \mathrm{C} / 11$ & $15,1 \pm 0,2$ & $13,1 \pm 0,1$ & $11,1 \pm 0,1$ & $6 \pm 0,0$ \\
\cline { 2 - 6 } & $237 \mathrm{YO} / 14$ & $16,1 \pm 0,1$ & $14,1 \pm 0,0$ & $12,0 \pm 0,0$ & $6 \pm 0,0$ \\
\cline { 2 - 6 } & $446 \mathrm{UB} / 15$ & $18,0 \pm 0,3$ & $16,0 \pm 0,1$ & $14,1 \pm 0,1$ & $6 \pm 0,0$ \\
\cline { 2 - 6 } & $524 \mathrm{YO} / 14$ & $15,2 \pm 0,3$ & $14,0 \pm 0,1$ & $12,1 \pm 0,1$ & $6 \pm 0,0$ \\
\cline { 2 - 6 } & $833 \mathrm{UB} / 14$ & $16,0 \pm 0,0$ & $14,1 \pm 0,2$ & $12,0 \pm 0,1$ & $6 \pm 0,0$ \\
\hline
\end{tabular}

\section{TC witness control}

\section{Effect of ATE of $B$. abyssinica on multi-resistant strains.}

After the incubation time at $37^{\circ} \mathrm{C}$, increasing concentrations of aqueous total extract have led to a gradual reduction of bacterial growth and a dose-dependent turbidity of the culture medium and that for each bacterial strain studied. The antibacterial parameters values obtained for each bacterial strain are reported in Table 3 . 
International Journal of Science and Research (IJSR)

ISSN (Online): 2319-7064

Index Copernicus Value (2013): 6.14 | Impact Factor (2014): 5.611

Table 3: Antifungal Parameters

\begin{tabular}{|c|c|c|c|c|c|}
\hline Strain & Codes & $M I C(\mathrm{mg} / \mathrm{ml})$ & $M B C(\mathrm{mg} / \mathrm{ml})$ & $M B C / M I C$ & Action \\
\hline \multirow{5}{*}{ Staphylococcus aureus } & $\mathrm{ATCC} 25923$ & $1,563 \pm 0,0$ & $1,563 \pm 0,0$ & 1 & Bactericidal \\
\cline { 2 - 7 } & $039 \mathrm{C} / 11$ & $0,391 \pm 0,0$ & $0,098 \pm 0,0$ & 0,251 & Bactericidal \\
\cline { 2 - 6 } & $237 \mathrm{YO} / 14$ & $0,195 \pm 0,0$ & $0,195 \pm 0,0$ & 1 & Bactericidal \\
\cline { 2 - 6 } & $446 \mathrm{UB} / 15$ & $1,563 \pm 0,0$ & $0,391 \pm 0,0$ & 0,250 & Bactericidal \\
\cline { 2 - 6 } & $524 \mathrm{YO} / 14$ & $1,563 \pm 0,0$ & $0,781 \pm 0,0$ & 0,500 & Bactericidal \\
\cline { 2 - 6 } & $833 \mathrm{UB} / 14$ & $1,563 \pm 0,0$ & $1,563 \pm 0,0$ & 1 & Bactericidal \\
\hline
\end{tabular}

\section{Discussion}

Of antibacterial activity is apparent that all multi-resistant strains of Staphylococcus aureus are sensitive to aqueous total extract ofstem bark of Bersama abyssinica compared to controls in a dose-response relationship.

We observed progressive increase of the inhibition zone as the concentration of the aqueous total extract increases. The diameters of the zones of inhibition ranged from $11.1 \pm 0.1$ to $18.0 \pm 0.3 \mathrm{~mm}$ for multi-resistant strains and from $11.2 \pm 0.2$ $\mathrm{mm}$ to $15.1 \pm 0.1 \mathrm{~mm}$ for the reference strain ATCC 25923 .

An extract is considered to be active when induced an inhibition zone higher or equal to $10 \mathrm{~mm}[18]$. The inhibition zone diameters are all greater than $10 \mathrm{~mm}$, it could be said that the aqueous total extract of the stem bark of $B$. abyssinica is active. The MICs found between $1.563 \pm 0.0$ and $0.195 \pm 0.0 \mathrm{mg} / \mathrm{ml}$ and $\mathrm{MBC}$ varies from $1.563 \pm 0.0$ and $0.098 \pm 0.0 \mathrm{mg} / \mathrm{ml}$.

The phytochemical study of the composition of the leaves, stem bark and root bark of $B$. abyssinica revealed the presence of 21 chemical compounds in the stem bark of which 1,2,3-benzenetriol (Pyrogallol) and 2 3dimethylfumaric acid (Fatty acid) they possessed antibacterial activities[19]. This would justify the antibacterial activity found on multidrug resistant $S$. aureus strains in our study.

Finally, the aqueous total extract of stem bark of $B$. abyssinica showed bactericidal activity against all bacterial strains tested, as the ratio MBC/MIC was less than 2 .

\section{Conclusion}

Our study has shown that the aqueous total extract of the stem bark of $B$. abyssinica hasantibacterial activity. All multi-resistant strains of Staphylococcus aureus as well as the reference strain studied were susceptible to the aqueous total extract of the leaves of $B$. abyssinica. ATE exhibit a bactericidal activity on various strains. This study justifies the traditional use of stem bark of Bersama in treating skin diseases. From the outcome of our study, the ATEof $B$. abyssinica opens a new path with respect to the search for new natural substances that can neutralize multi-resistant strains. Bersama abyssinica is a natural antibiotic.

\section{Acknowledgments}

We thank the Laboratory of Biochemistry and Microbiology of the Ecole Normale Supérieure (ENS) for the extraction and the Department of Bacteriology and Virology of the
Pasteur Institute of Cote d'Ivoire (IPCI), for antibacterial activity analysis.

\section{References}

[1] RE Hancock, The end of an era. Nat Rev Drug Discov. $6: 28$ DOI :10.1038/nrd2223, 2007.

[2] ML Cohen, Changing patterns of infectious disease, Nature 17: 762-767, 2000.

[3] I Ahmad, AZ Beg, Antimicrobial and phytochemical studies on 45 Indian medicinal plants against multidrug resistant human pathogens. J Ethanopharmacol., $74: 113-123,2001$.

[4] N Guessennd, VC Gbonon, KB Tiékoura, A KakouN'douba, DN Ouattara, C Boni-Cissé, M Dosso et le GER-BMR, Évolution de la résistance bactérienne à l'imipénème en Côte d'Ivoire de 2005 à 2009. Colloque scientifique de l'Institut Pasteur de Côte d'Ivoire: pathologies émergentes et biologie intégrative, 17 p, 2009.

[5] $\mathrm{T}$ Verdier, $\mathrm{G}$ Lina, $\mathrm{Y}$ Gillet et $\mathrm{F}$ Vandenesch,Staphylococcus. Cours de Bactériologie Médicale,

2001.[Online] Available:http://www.microbes-edu.org/ consulté le 14 janvier 2010.

[6] CJ Soussy, JD Cavallo, H Chardon, C Chidiac, P Courvalin, H Dabernat, H Drugeon, L Dubreuil, B Guery, V Jarlier, T Lambert, R Leclercq, MH Nicolas Chanoine , CQuentin, B Rouveix, et E Varon, Comité de l'antibiogramme de la Société Française de Microbiologie. Edition de Janvier. 59p, 2012.

[7] JN Eloff , Which extractant should be used for the screening and isolation of antimicrobial components from plants? Journal of Ethnopharmacology 60 : 1-8, 1998.

[8] V Kuete, AT Mbaveng, M Tsaffack, V Penlap Beng, F-X Etoa, AE Nkengfack, JJ Marion Meyer, N Lall, Antitumor, antioxidant and antimicrobial activities of Bersama engleriana (Melianthaceae). Journal of Ethnopharmacology115: 494-501, 2008.

[9] N Zekeya, F Shahada, M Chacha,In vitro Antibacterial and Antifungal Activity of Tanzanian Bersama abysinica. International Journal of Science and Research, 3(7) : 1150-1153, 2014.

[10] GN Zirihi, Études botanique, pharmacologique et phytochimique de quelques plantes médicinales antipaludiques et/ou immunogènes utilisées chez les Bétés du Département d'Issia, dans l'Ouest de la Côted'Ivoire. Thèse de Doctorat d'Etat, Université de Cocody-Abidjan, Côte d'Ivoire, 181 p., 2006.

[11] GN Zirihi, K N'guessan, DT Etien and P Grellier, Ethnopharmacological study of plants used to treat malaria, in traditional medicine, by Bete Populations of 


\section{International Journal of Science and Research (IJSR) \\ ISSN (Online): 2319-7064}

Index Copernicus Value (2013): 6.14 | Impact Factor (2014): 5.611

Issia (Côte d'Ivoire). J. Pharm. Sci. \& Res. 2(4) : 216$227,2010$.

[12] L Aké-Assi, Flore de la Côte d'Ivoire: catalogue systématique, biogéographie et écologie. Conservatoire et Jardin Botanique, Génève, Switzerland, Boisiera 57; Volume I : 396 p., 2001.

[13] D Kouamé, Travaux Pratiques de Microbiologie alimentaire (BCH 44), Abidjan (Côte d'Ivoire), 60p, 2005.

[14] GN Zirihi, AKM Kra et F Guédé-Guina,Évaluation de l'activité Antifongique de Microglossa pyrifolia (LAMARCK) O. KUNTZE (ASTERACEAE) « PYMI " sur la croissance in vitro de Candida albicans. Revue de Médecine et de Pharmacopées Africaines ; 17 : 11 $18,2003$.

[15] K Béné, D Camara, N'GBY Fofié et GN Zirihi, Étude ethnobotanique, activité antifongique in vitro sur Candida albicans et toxicité sur les cellules HFF de Harrisonia abyssinica Oliv. (Simaroubaceae), une plante de la pharmacopée ivoirienne. Journal of Applied Biosciences 94 : 8815-8824, 2015.

[16] AG Ponce, R Fritz, C Del Alle, SI Roura, Antimicrobial activity of essential oil on the native microflora of organicSwiss chard. LebensmittelWissenschaft und Technologic, 36 : 679-684, 2003.

[17] I-L Fauchere etJ-L Avril, Bactériologie générale médicale. Editions Ellipses. 122p.

[18] LFBiyiti, DJL Meko'o, V Tamzc, PH Amvam Zollo, Recherche de l'Activité Antibactérienne de Quatre Plantes Médicinales Camerounaises. Pharm. Méd. Trad. Afr., 13: 11-20, 2004.

[19] N Zekeya, M Chacha, F Shahada \& A Kidukuli, Analysis of phytochemical composition of Bersama abyssinica by gas chromatography - mass spectrometry. Journal of Pharmacognosy and Phytochemistry 3(4) : 246-252, 2014.

\section{Author Profile}

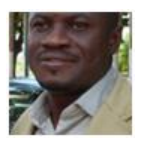

Kouadio BENE received Master in Biodiversity and Ecosystem Valuation from University of Felix Houphouet-Boigny under the supervision of Prof. Guede N. ZIRIHI in 2014. Now I am a PhD student (Ethnobotany-Ethnopharmacology) on Laboratory of Botany (Natural Substances Unit). UFR Biosciences, University Félix Houphouet Boigny , 22 BP 582 Abidjan 22, .Abidjan, Côte d'Ivoire. 